\title{
Enzyme activity and biochemical parameters in racing pigeons (Columba livia domestica) during flight effort
}

\begin{abstract}
In this research the work focuses on monitoring changes in selected biochemical indicators determining the muscular and metabolic strain on racing pigeons over a $300 \mathrm{~km}$ race. Flight effort in the pigeons induces a series of normal physiological and biochemical adaptations. Examining blood for their constituents can provide important information of exposed animals to muscle load and the fatigue. Prior to and at the end of the race, blood samples were withdrawn from the vena metatarsalis from 14 pigeons, and the levels of creatine kinase (CK), alanine aminotransferase (ALT), aspartate aminotransferase (AST), alkaline phosphatase (ALP), lactate dehydrogenase $(\mathrm{LDH})$ as well as lactate (LAC), glucose (GLU), uric acid (UA), creatinine (CRE), cholesterol (CHOL), total protein (TP) and calcium $(\mathrm{Ca})$ were measured. After the race, increased enzyme activity (CK, AST, ALT) was shown to be a good indicator of muscle strain during the flight, indicating together with elevated ALP, LDH, LAC, serum intracellular protein and CRE levels the degree of muscle damage as well as the recovery time of individual birds. The finding of reduced CHOL values, moreover, confirmed that the increased oxidation of free fatty acids in the serum also corresponded to a decrease in the level of GLU.
\end{abstract}

Keywords: flight effort, racing pigeons, muscular and metabolic strain, serum levels, increased enzyme activity
Volume 3 Issue 6 - 2018

\author{
František Zigo,' Silvia Ondrašovičová, \\ Ladislav Takáč, ${ }^{3}$ Zuzana Farkašová,' Martina \\ Zigová, ${ }^{4}$ Jana Takáčová ${ }^{3}$ \\ 'Department of Animal husbandry, University of Veterinary \\ Medicine and Pharmacy, Slovakia \\ ${ }^{2}$ Department of Physiology, University of Veterinary Medicine \\ and Pharmacy, Slovakia \\ ${ }^{3}$ Institute of Judicial and Public Veterinary Medicine and \\ Economics, University of Veterinary Medicine and Pharmacy, \\ Slovakia \\ ${ }^{4}$ Department of Pharmacology, University of Pavol Jozef Šafárik \\ in Košice, Slovakia
}

\begin{abstract}
Correspondence: František Zigo, University of Veterinary Medicine and Pharmacy, Department of Animal husbandry, Komenského 73,04I 8I Košice, Slovakia, Tel +421-908-689-722,
\end{abstract} Email frantisek.zigo@uvlf.sk

Received: November 26, 2018 | Published: December 26, 2018

\section{Introduction}

Since the oldest times, pigeons attracted the interest of people by their unbelievable sense of spatial orientation, flying capabilities, monogamous behaviour and bond to their habitat. By successfully returning from the race in a winning position, the pigeons demonstrate favourable factors, such as their inherent qualities, health state, stress related to transport and hygiene conditions in their breeding environment. Shortened flying times at competitions and more races per season indicate the higher performance of these birds which is reflected in their health and short periods of regeneration. ${ }^{1,2}$

During flight, ATP is catabolized to adenosine diphosphate and further to adenosine monophosphate and inosine phosphate in the muscle fibers. This process is accompanied by glycogen consumption and increasing glucose-3-phosphate, glycerol, and lactate concentrations. Exercise-induced processes are reflected in changes in blood constituents. ${ }^{3-5}$ Biochemical values are good reflector of exposed animals to muscle load and the fatigue of the body. Examining blood for their constituents can provide important information for the diagnosis and prognosis of diseases in animals. ${ }^{6,7}$

Since metabolic and muscular enzymes are characterized by a very wide range of activity, the interpretation of variations of these enzymes is difficult. Nevertheless, these enzymes may be adversely affected by factors such as muscular injury, rupture of organs, nutritional status, physical activity, hemolysis, treatment, and conservation of samples and their levels in blood can increase. Also, these enzymes can be an important diagnostic tool in veterinary sport medicine. ${ }^{8-10}$ The aim of the present study was to monitor changes in selected biochemical indicators determining the muscular and metabolic strain on racing pigeons during a $300 \mathrm{~km}$ flight.

\section{Material and methods}

\section{Breeding facilities}

A wooden loft (garden-type) measuring $7.5 \mathrm{~m} \times 2.5 \mathrm{~m} \times 2 \mathrm{~m}$ with capacity for 80 carrier pigeons (Columba livia dom.) was used, divided with mesh into two main sections for males and females. Each section consisted of a pull-out box with slatted floor and also one feedpump and a feeder. In February, before the race season, the pigeons were mated and reared one squab together to consolidate themselves as a pair, and thus have greater incentive to return home. After the squabs were removed, the pigeons flew around the loft for short flight distances from 10 to $40 \mathrm{~km}$.

\section{Training and racing of pigeons}

During the flight season (May to July) training and racing were carried out according to the season plan. The pigeon races were divided regarding the distance into short, medium and long races, with ranges between $140 \mathrm{~km}$ up to $1200 \mathrm{~km}$. Breeders who are interested in participating in a race must report their name, coordinates of their loft, and confirm ownership of the pigeon they are placing in the race. Pigeons should be clinically healthy with a valid identification number (ring) and a chip which is updated and retrieved in the electronic registration system while the pigeons are being loaded into the transport boxes. The pigeons in their boxes are then loaded into a specially modified lorry, which takes them to a predetermined starting point. There, at the command of the starter, all the pigeons are released from the boxes at once. The exact time of arrival of each racer at the loft is registered by the electronic recording system as it reads the pigeon chip located on the landing platform. Based on the recorded time and calculated GPS data, the coordinates in the electronic system of each fancier determine the order of arrival of individual pigeons from the race. In each race, however, only $20 \%$ of the total number of pigeons deployed will receive an overall ranking (Figure 1). 

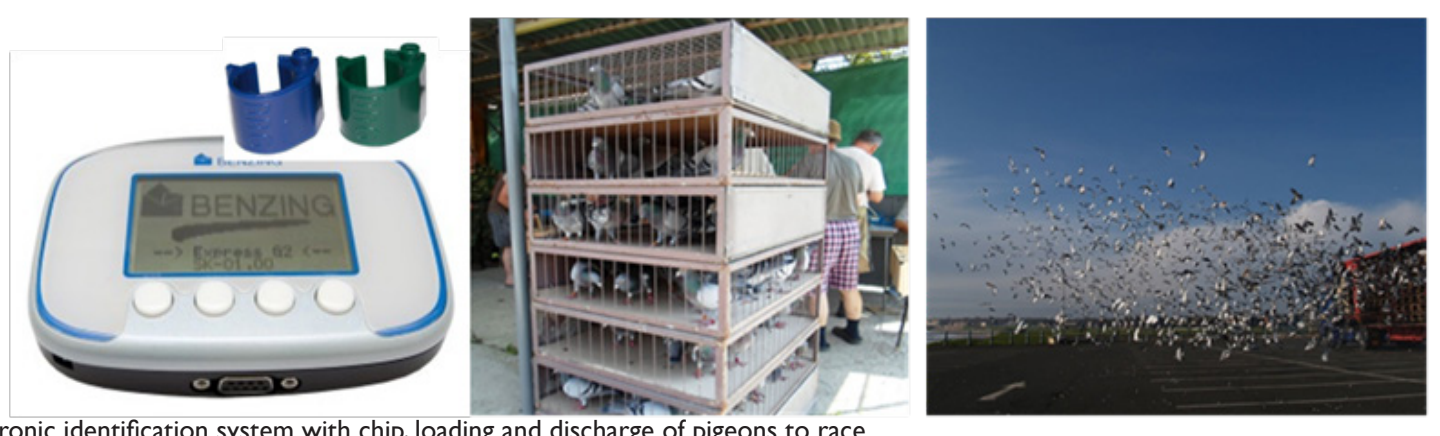

Figure I Electronic identification system with chip, loading and discharge of pigeons to race.

\section{Selection of pigeons and sample analysis}

The experimental part of the work was selected for 7 females and 7 male pigeons with average weights of $470 \mathrm{~g}$ and $495 \mathrm{~g}$ respectively, which took part in a medium-length race in the range of $300-338$ $\mathrm{km}$. The flight duration was 3 hours and $20 \mathrm{~min}$. at an average speed of $92 \mathrm{~km} / \mathrm{h}$. Two days before the flight and again after the pigeons' arrival home from the race, blood samples were collected from the vena metatarsalis of each bird into non-heparinized bottles for serum biochemistry. After clotting, the serum tubes were centrifuged and the harvested serum was transferred to plastic tubes and stored at $4{ }^{\circ} \mathrm{C}$ before analysis.

Biochemical analyses such as enzymatic activity of creatine kinase (CK), alanine aminotransferase (ALT), aspartate aminotransferase (AST), alkaline phosphatase (ALP) lactate dehydrogenase (LDH) as well as levels of lactate (LAC), glucose (GLU), uric acid (UA), creatinine (CRE), cholesterol (CHOL), total protein (TP) and calcium (Ca) were tested by the use of automatic analyzator Unicel DxC 880i (Beckman Coulter, USA) using the commercial kits Labtest according to the methods described by Duncan et al. ${ }^{11}$

\section{Statistical analysis}

Table I The values of muscle and metabolic enzymes of racing pigeons
A paired t-test was used to evaluate the biochemical values before and after the race. Differences were considered as significant at the level of $\mathrm{p} \leq 0.05$. The results are presented as mean values $(\mathrm{M}) \pm$ standard deviation (SD).

\section{Results and discussion}

Physical stress causes dramatic changes in fluid volume, metabolites and ion concentrations in the muscles, which can aggravate muscle performance. Changes in serum electrolyte, enzyme and metabolite values reflect sweating, muscle damage and increased dependence on anaerobic glycolysis and fat mobilization during physical exercise. ${ }^{8,12}$

Table 1 compares the mean values of selected biochemical markers in pigeon blood serum two days before the race and after arrival home. After the race, elevated $(\mathrm{P}<0.05)$ enzymatic activity CK, ALT, AST was recorded, which is a good indicator of muscle load during the race. Together with elevated ALP, LDH, serum intracellular protein and CRE concentrations, these indicate the rate of muscle damage after the race as well as the recovery time of the individual (Table 1). Similarly, higher activities of creatine kinase (CK), lactate dehydrogenase (LDH), alkaline phosphatase, aspartate aminotransferase and gamma glutamyltransferase were documented. ${ }^{13-15}$

\begin{tabular}{lllllll}
\hline Parameters & Unit & Ref. values* & Before race & After race & P & $\%$ \\
\hline AST & IU/L & $45-123$ & $107 \pm 9.0$ & $258 \pm 24.5$ & $\mathrm{P}<0.001$ & $14 \mathrm{I}$ \\
ALT & IU/L & $5-45$ & $23.6 \pm 2.8$ & $37.3 \pm 5.4$ & $\mathrm{P}<0.001$ & 60 \\
ALP & IU/L & $24-104$ & $126.4 \pm 10.1$ & $374.2 \pm 28.3$ & $\mathrm{P}<0.001$ & 197 \\
CK & IU/L & $110-480$ & $257.5 \pm 36.2$ & $511.3 \pm 41.0$ & $\mathrm{P}<0.001$ & 99 \\
LDH & IU/L & $30-205$ & $128 \pm 10.7$ & $267 \pm 30.6$ & $\mathrm{P}<0.001$ & 109 \\
\hline
\end{tabular}

Legend: P - Significance level, \% - percentage difference between the compared values before and after race. Ref. values* - Harr ${ }^{21}$ and Fudge. ${ }^{18}$

The release of cytoplasmic enzymes, including CK, AST and $\mathrm{LDH}$, is considered to be a suitable parameter for the evaluation of muscle injury during exercise. ${ }^{16}$

CK is among the most important muscle-specific enzymes and it is present in tissues as a specific isoenzyme. The determination of this isoenzyme is clinically used as a diagnostic tool in musculoskeletal disease.${ }^{17}$ The rise in CK level is mainly due to strength and extreme endurance training, and its elevated level can be observed between 2 and 12 hours after effort. In addition to physical exercise, CK elevation also contributes to ionic imbalance in the form of hyponatremia or hypokalemia, age, gender differences and viral diseases. ${ }^{1,18}$ Other enzymes released due to muscle fiber damage are AST and ALT. ${ }^{7,19,20}$ AST activity is currently considered as a very sensitive but non-specific indicator of hepatocellular disease in avian species, and is frequently used with the muscle specific enzyme CK to differentiate between liver and muscle damage. Elevated plasma AST and CK activity demonstrates muscle cell damage and leakage of these enzymes into the circulatory system (Table 1$).{ }^{8}$

Upon arrival of the pigeons, decreased CHOL values were observed, which corresponds to increased oxidation of free fatty acids in serum and decreased GLU level (Table 2). In addition, while the body burns fat reserves during physical effort, other important substances such as calcium, magnesium, potassium and sodium are lost. These elements play an important role in the proper functioning of the body. ${ }^{8,12}$ Harr $^{21}$ reported calcium content in pigeon blood of $7.6-10.4 \mathrm{mg} / \mathrm{dL}$. Our finding of calcium content before the race 
was $2.08 \mathrm{mmol} / \mathrm{L}$. Measuring calcium content after $300 \mathrm{~km}$ of racing revealed its slight decline. Similar results were obtained by Santos et al. ${ }^{13}$ in racehorses, where the calcium level dropped during a 50-mile endurance ride and remained significantly low in the sample after 16 hours of racing. The decrease in concentration is explained by the fact that during muscle contraction, calcium attaches to the troponin molecule to allow for the binding of actin and myosin, so the calcium ions are transferred to the intracellular space to provide sufficient muscle function.

Table 2 The values of serum biochemical parameters of racing pigeons
During flight, all sources of energy are metabolized to muscle and heat to produce lactate (lactic acid). In very intense (anaerobic) flight activity, lactate is more rapidly accumulated in tissues than it is degraded and causes acidification, resulting in so-called hardening of the breast muscles. Rapid onset of muscle fatigue is the cause of a slowdown and such pigeons drop exhausted to the ground. In the best case these pigeons will come home, but with greater or lesser delays. With such a pigeon there is a great problem with its regeneration and further preparation for the next performance if there is only a short time between races (Table 2).

\begin{tabular}{lllllll}
\hline Parameters & Unit & Ref. values* & Before race & After race & $\mathbf{P}$ & $\%$ \\
\hline $\mathrm{CHOL}$ & $\mathrm{mg} / \mathrm{dL}$ & $100-200$ & $233.8 \pm 27.5$ & $158.3 \pm 17.1$ & $\mathrm{P}<0.001$ & -32 \\
$\mathrm{GLU}$ & $\mathrm{mg} / \mathrm{dL}$ & $232-470$ & $349 \pm 39.2$ & $243 \pm 27.3$ & $\mathrm{P}<0.001$ & -30 \\
$\mathrm{Ca}$ & $\mathrm{mg} / \mathrm{dL}$ & $7.6-10.4$ & $5.08 \pm 0.16$ & $3.6 \pm 0.22$ & $\mathrm{P}<0.01$ & -26 \\
$\mathrm{TP}$ & $\mathrm{g} / \mathrm{L}$ & $21-45$ & $39 \pm 4.6$ & $61 \pm 7.4$ & $\mathrm{P}<0.001$ & 56 \\
$\mathrm{UA}$ & $\mathrm{mg} / \mathrm{dL}$ & $2.5-12.6$ & $4.2 \pm 0.3$ & $7.8 \pm 0.8$ & $\mathrm{P}<0.001$ & 86 \\
$\mathrm{CRE}$ & $\mathrm{mg} / \mathrm{dL}$ & $0.26-0.4$ & $0.47 \pm 0.08$ & $0.87 \pm 0.12$ & $\mathrm{P}<0.001$ & 85 \\
$\mathrm{LAC}$ & $\mathrm{mg} / \mathrm{L}$ & $45-200$ & $143 \pm 11.5$ & $236 \pm 28.7$ & $\mathrm{P}<0.001$ & 65 \\
\hline
\end{tabular}

P - Significance level, \% - percentage difference between the compared values before and after race. Ref. values* - Harr ${ }^{21}$ and Fudge. ${ }^{18}$

\section{Conclusion}

Monitoring of muscular enzyme activity and biochemical parameters in racing pigeons can provide a critical evaluation of the level of membrane permeability caused by their flight effort. Different expressions of enzyme activity throughout a race, which are directly related to its duration, were found and can be used as a tool for checking the amount of muscle alteration and the recovery time for pigeons submitted to this exercise. Acquired knowledge of metabolic and antioxidant processes taking place in the pigeon body during flight help us in particular with the selection of suitable individual racers which can be loaded with intensive training and expected to produce an adequate result.

\section{Acknowledgments}

None.

\section{Conflicts of interests}

Author declares that there is no conflict of interest.

\section{References}

1. Costantini D, Dell'Ariccia G, Lipp HP. Long flights and age affect oxidative status of homing pigeons (Columba livia). $J$ of Exp Bio. 2008;211:377-338

2. Zigo F, Takáč L, Chripková M, et al. Infectious diseases of carrier pigeons and antimicrobial resistance in isolated bacteria. Int $J$ of $S c i$ Res. 2006;5:2277-8179.

3. Harris DB, Harris RC, Wilson AM, et al. ATP loss with exercise in muscle fibres of the gluteus medius of the thoroughbred horse. Res Vet Sci.1997;63(3):231-237.

4. Coenen M. Exercise and stress: Impact on adaptive processes involving water and electrolytes. Liv Prod Sci. 92:131-145.

5. Seidlmayer LK, Blatter LA, Pavlov E, et al. Inorganic polyphosphate- an unusual suspect of the mitochondrial permeability transition mystery. Channels (Austin). 2012;6(6):463-467.

6. Joshi PK, Bose M, Haris D. Changes in certain haematological parameters in asiluroid catfish Clarias batrachus (Linn) exposed to a cadmium chloride. Pollution Res. 2002;21(2):129-131.

7. Lee J, Clarkson PM. Plasma creatine kinase activity and glutathione after eccentric exercise. Med and Sci in Spo and Ex. 2003;35(6):930936.

8. Hargreaves BJ, Kronfeld DS, Waldron JN, et al. Antioxidant status and muscle cell leakage during endurance exercise. Equine Vet $J$ (suppl). 2002;34:116-121

9. Teixiera Neto AR, Ferraz GC, Moscardini AR, et al. Alterations in muscular enzymes of horses competing long-distance endurance rides under tropical climate. Bras Med Vet Zootec. 2008;60(3):543-549.

10. Zigo F, Takac L, Zigova M, et al. Effect of Dietary Selenium Sources in Racing Pigeons and their Effect on Antioxidant Markers During Flying Effort. Int J Avian \& Wildlife Biol. 2007;2(5):00035.

11. Duncan JR, Prasse KW, Mahaffey EA. Veterinary laboratory medicine, clinical Pathology. USA: Iowa State University Press; 1994.

12. Fielding CL, Magdesian KG, Rhodes DM, et al. Clinical and biochemical abnormalities in endurance horses eliminated from competition for medical complications and requiring emergency medical treatment: 30 cases (2005-2006). J vet Emerg Crit Care. 2009;19(5):473-478.

13. Santos SA, Silva. Serum electrolyte and total protein alterations in Pantaneiro horses during long distance exercise. Arq Bras Med Vet Zootec. 2001;53:351-357.

14. Hand O. The Effects of Stress on Racing Pigeons. Pigeonbasics. 2004.

15. Schoonheere N, Dotreppe O, Pincemail J, et al. Dietary incorporation of feedstuffs naturally high in organic selenium for racing pigeons (Columba livia): effects on plasma antioxidant markers after a standardised simulation of a flying effort. J Anim Physiol Anim Nutr (Berl). 2009;93(3):325-330. 
16. Da Cás EL, Rosauro AC, Silva CA, et al. Concentração sérica das enzimas creatinoquinase, aspartato aminotransferase e hidrogenase láctica em eqüinos da raça crioula Cien. Rural. 2000;30:625-629.

17. Clarkson PM, Kearns AK, Rouzier P, et al. Serum creatine kinase levels and renal function measures in exertional muscle damage. Med and Sci in Spo and Exer. 2006;38(4):623-627.

18. Fudge AM. Laboratory Medicine avian and Exotic Pets. Philadelphia: Saunders; 2000. p. 486
19. Cohen ND, Roussel AJ, Lumsden JH, et al. Alterations of fluid and electrolyte balance in thoroughbred acehorses following strenuous exercise during training. Can J Vet Res. 1993;57:9-13.

20. Mills PC, Smith NC, Casas I, et al. Effects of exercise intensity and environmental stress on indices of oxidative stress and iron homeostasis during exercise in the horse. Eur J Appl Physiol. 1996;74:60-66.

21. Harr EK. Clinical chemistry of companion avian species: a review. Vet Clin Pathol. 2002;31(3):140-51. 